\title{
Shading Induced Variability in Azalea Mediates its Suitability as a Host for the Azalea Lace Bug
}

\author{
Jo-Ann Bentz ${ }^{1}$ \\ U.S. National Arboretum, Floral and Nursery Plants Research Unit, U.S. Department of Agriculture, \\ Agricultural Research Service, 10300 Baltimore Avenue, BARC-West, Building O10A, Room 238, \\ Beltsville, MD 20705-2350
}

\begin{abstract}
ADDITIONAL INDEX wORDS. Rhododendron mucronatum, oviposition, nymphal survivorship, feeding injury, leaf nutrients, leaf physical characters, Stephanitis pyrioides

Aвstract. This study quantified how different shading levels alter the foliar nutrient, $\mathrm{C}: \mathrm{N}$ ratio, chlorophyll content and key leaf characters in azalea 'Delaware Valley White' Rhododendron mucronatum (Blume) (Ericales: Ericaceae), which influenced, in turn, feeding, oviposition, survival and development of the azalea lace bug, Stephanitis pyrioides (Scott) (Heteroptera: Tingidae). The mean contents of $\mathrm{N}, \mathrm{Ca}, \mathrm{Fe}$, and $\mathrm{Zn}$ increased linearly with increases in the shading level, whereas $\mathrm{P}, \mathrm{K}, \mathrm{B}, \mathrm{Mn}$, and the $\mathrm{C}$ : $\mathrm{N}$ ratio of leaves were significantly decreased. Although injured leaves contained significantly less chlorophyll than uninjured leaves, the mean relative chlorophyll content of leaves increased linearly with the level of shading. Mean leaf area and moisture content of leaves increased linearly with increased degree of shading, while the mean trichome density decreased. The mean number of oviposited eggs and the percent of nymphs reaching adulthood increased linearly with the degree of shading. Azalea shoots suffered increased feeding injury as the season progressed, yet unshaded plants suffered more feeding injury than shaded plants. While the mean number of eggs laid, and the mean number of reared adults, were significantly and positively correlated with the mean leaf $\mathrm{N}$, the mean feeding injury was negatively correlated with leaf $\mathbf{N}$. Although these dependent variables were not correlated with $\mathrm{K}$ nor $\mathrm{Ca}$, the mean number of eggs laid, and the mean number of reared adults were negatively correlated with the mean leaf $P$ and with the mean $C: N$ ratio. Mean feeding injury was positively correlated with leaf $P$ and with the $C: N$ ratio, but negatively correlated with $\mathrm{N}$. This study shows that shaded plants are of better quality as hosts and that these plants can tolerate infestations by the lace bug.
\end{abstract}

Azalea, Rhododendron spp. (Ericales: Ericaceae), is one of the most widely planted ornamental shrubs in Southern California and in the Mid-Atlantic, Southeast, and Gulf Coast states. Thousand of cultivars have been developed, and thus can be found in a variety of micro-habitats (Galle, 1987). The azalea lace bug, Stephanitis pyrioides (Scott) (Heteroptera: Tingidae) is the primary pest problem affecting the aesthetic value and beauty of azaleas in landscape settings and its growth in production nurseries (Neal and Douglass, 1988). Feeding by the azalea lace bug on leaf mesophyll causes chlorotic spots or stipplings to develop on the upper surface of the leaves. Cast skins of nymphs and the tar-like excrement of this insect cause further leaf discoloration (Braman and Pendley,1992; Buntin et al., 1996; Coffelt and Schultz, 1988).

Because light has a marked influence on the growth of azaleas (Bodson, 1983; Hendricks and Borthwick, 1963; Kessell, 1990; Mohr, 1964; Pettersen, 1976), the performance of the azalea lace bug on plants growing under sunlight or shade has been the focus of several studies with conflicting results (Braman et al., 2000; Kintz and Alverson, 1999; Trumbule and Denno, 1995). Raupp (1984) found that azaleas that received afternoon sun only, or all day sun, were more frequently infested by lace bugs than azaleas receiving morning sun only. Trumbule and Denno (1995) reported that lace bugs preferred to feed and oviposit on

Received for publication 23 Sept. 2002. Accepted for publication 7 Mar. 2003. thank Amy Barbosa, Clara Fuentes, Dana Kistler, Nikhil Mallampalli, and Chri Scovitch, for their assistance with experiments (USDA, ARS, USNA, FNPRU), and to Pedro Barbosa (University of Maryland), Robert Griesbach (USDA, ARS), and Fernando Vega-Sanchez (USDA, ARS), for comments on the manuscript. Mention of a proprietary product does not constitute an endorsement or a recommendation by the USDA for its use.

'Research entomologist. shade-grown instead of sun-grown azaleas, and speculated that the higher rates of insect predation in shaded habitats were responsible for the reduced survival of lace bugs in these habitats. Kintz and Alverson (1999) reported that growing azaleas in sun or shade has no effect on lace bug populations when the plants are grown in a monoculture environment. Shrewsbury and Raupp (2000) determined that landscape structure and light exposure were the best predictors of azalea lace bug abundance, rather than host patch size or plant species diversity, evenness, and richness. Although the results of these studies are contradictory, they still suggest that shading influences population numbers of the azalea lace bug.

It is possible that the behavior or performance of the azalea lace bug is influenced in part by the quality of the host plant when shaded (Scriber, 1984; Slansky and Scriber, 1985). Available data indicate that plants differ physiologically, chemically, and morphologically when in shade versus in sun (Bultman and Faeth, 1988; Collinge and Louda, 1988; Crone and Jones, 1999; Dudt and Shure, 1994; Lincoln and Mooney, 1984; Louda and Rodman, 1996; Maiorana, 1981; Potter, 1992; Rowe and Potter 2000; Schaffer and Mason, 1990). Thus, the impact on lace bugs may be reflected in host plant feeding preferences, development, survival or fecundity. It is probable that changes in lace bug abundance due to sun or shade induced changes in the suitability of azalea as a host plant may be a causal mechanism.

This study aimed to determine the effect of shading on the suitability and utilization of azalea as a host by the azalea lace bug. Specific objectives were to 1) quantify how shading alters foliar nutrient and chlorophyll content and key leaf characters in azalea, which may influence the insect's behavior, and 2) determine if feeding injury and azalea lace bug oviposition, survival and development differ when on azaleas under different sunlight regimes. 


\section{Materials and Methods}

INSECT COLONY. A laboratory colony of the azalea lace bug was started in the summer of 1997 and invigorated yearly with adults collected from an azalea field plot at the Henry A. Wallace Beltsville Agricultural Research Center (BARC), USDA-ARS, Beltsville, Md. Insects were reared on cuttings of greenhouse grown azalea (Rhododendron mucronatum Blume 'Delaware Valley White'), placed in water-filled glass bottles which were kept in clear plastic cages $(60 \times 60 \times 30 \mathrm{~cm}$ or $60 \times 60 \times 60 \mathrm{~cm})$. Cages containing the cuttings with insects were maintained in a walk-in environmental chamber at $25.5^{\circ} \mathrm{C}, 60 \%$ to $80 \%$ relative humidity, and a photoperiod of 16:8 (L:D) h.

FiELD PLOT. Twenty four plants in 18.93 liter plastic pots of the commercially available cultivar Delaware Valley White, were purchased in the late-summer of 1995, and planted in a completely randomized block design (CRBD) in a field plot at BARC, with six rows of four plants each. This cultivar was chosen because of its relative high susceptibility to lace bug feeding injury (Schultz, 1993). Plants were $3.05 \mathrm{~m}$ equidistant from each other. Each plant within each row was assigned a shade level, i.e., $0 \%, 25 \%$, $50 \%$, or $75 \%$ shading. Except for plants assigned the $0 \%$ shading treatment, wood framed cages $(1.22 \times 0.61 \times 0.61 \mathrm{~m})$, were built around each plant and covered with a black shade-cloth, rated to produce the designated shade level. Shade cloth ratings are approximations for the amount of light blocked, i.e., $25 \%$ to $30 \%, 50 \%$ to $55 \%$, or $73 \%$ to $75 \%$. The top of the cage was completely covered while the top one-half of the west-facing side of the cage and the top one-third of the other three sides were covered. By allowing the bottom of the sides to be uncovered, mowing, watering and handling of plants was facilitated without disruption of the plant.

Light measurements were taken using a quantum meter (model BQM; Apogee Instruments, Inc., Logan, Utah) over the plant's canopy, but about $0.15 \mathrm{~m}$ below the shade cloth for those plants that were shaded. Two readings were taken, about 2 min apart, for each plant on 27 June, 30 June, 3 July, 6 July, 24 July, 27 July, 31 July and 3 Aug. 2000. The data showed that the mean amount of photosynthetic photon flux decreased linearly with increased degree of shading (Mean PPF \pm SEM: $0 \%=783 \pm 60 ; 25 \%=$ $\left.600 \pm 60 ; 50 \%=360 \pm 60 ; 75 \%=139 \pm 60 \mu \mathrm{mol} \mathrm{m}{ }^{-2} \mathrm{~s}^{-1}\right)(P=$ $0.0243 ; R^{2}=0.95 ; y=732-8 x$ ).

ELEMENTAL ANALYSES AND C:N RATIO of FOLIAGE. Leaf samples were collected by randomly cutting two shoots from each plant on 16 July 1998, 30 July 1998, 8 June 1999 and 22 June 1999. Shoots were brought to the laboratory where the leaves, with the petioles attached, were removed, pooled, weighed fresh, and stored at $-20^{\circ} \mathrm{C}$ in the freezer until ready to be analyzed. Samples weighing at least $10 \mathrm{~g}$ fresh weight were submitted to a commercial analytical laboratory for element content determination (Brookside Laboratories, Inc., New Knoxville, Ohio). Samples were digested in a nitric acid /hydrogen peroxide microwave digestion system (model 2100; CEM-MDS, Matthews, N.C.) All elements, except $\mathrm{N}$, were analyzed using an inductively coupled plasma spectrometer (ICP) (model 61E; Thermo Jarrell Ash, Waltham, Mass.). Total $\mathrm{N}$ and $\mathrm{C}$ were determined using a Carlo Erba nitrogen-carbon-sulfur analyzer (model NA 1500 ; Milan, Italy). Data were pooled by block, a mean calculated for each treatment within each block, and analyzed using multivariate regression. Also, principal components analysis with 11 variables (i.e., $\mathrm{N}, \mathrm{P}, \mathrm{K}, \mathrm{Ca}, \mathrm{Mg}, \mathrm{S}, \mathrm{B}, \mathrm{Fe}, \mathrm{Mn}, \mathrm{Zn}$, and $\mathrm{Cu}$ ) was used to reduce the dimensionality of the data and summarize variability among shading levels using a correlation matrix after standardizing the data to unit variance (SAS Institute, 1999).

A mean C:N ratio was calculated for each shade level using 20 samples that had been collected at random as described above, and analyzed using regression techniques.

LEAF CHLOROPHYLL CONTENT. Chlorophyll content was determined using a Minolta chlorophyll meter (model SPAD -502; Spectrum Technologies, Inc., Plainfield, Ill.). This instrument determines the relative amount of chlorophyll present by measuring the absorbance of the leaf in two wavelength regions. Four, fully expanded mature leaves per plant were selected and measured on 18 Aug. 2000. Two of the chosen leaves exhibited stippling injury in $>75 \%$ of the leaf blade, and the other two leaves were not showing injury. Thus, leaves were categorized as either injured or uninjured. Data were pooled, a mean calculated for each treatment and analyzed using regression techniques with leaf injury category coded as a dummy variable. The dummy variable facilitated testing the effect of leaf injury category on leaf chlorophyll regressed against shading level (Aiken and West, 1991).

LEAF MEASUREMENTS. Shoots from the top of the plant were randomly selected, cut off and collected weekly from 16 July to 20 Aug. 1998, and weekly from 8 June to 24 June 1999. Shoots were brought to the laboratory where 10 leaves were randomly collected from each shoot. Leaf area of the 10 leaves was measured using an area meter (model LI-3100; LI-COR, Lincoln, Nebr.). The 10 leaves were then divided into two groups; one group was used for calculating trichome density and the other group was used for determining dry biomass weight using a moisture determination balance (model Ohaus MB 200; Seedburo Equipment Co., Chicago, Ill.). Trichome density was determined using a stereomicroscope set at $200 \times$ magnification, by counting the number of trichomes within a $1 \mathrm{~cm}$ diameter per leaf. Leaf area, trichome density and percent moisture content of leaves data were pooled among the different dates, a mean calculated for each treatment and analyzed using regression techniques.

LACE BUG FECUNDITY. Weekly from 16 July to 20 Aug. 1998, from 8 to 24 June 1999, and 11 to 18 July 2000, lace bug females were collected from the laboratory colony, placed in a cooler, and transported to the field plot. At the field plot, lace bugs were transferred in groups of two into white organza sleeve cages (30.48 $\times 38.10 \mathrm{~cm}$ ). The sleeve cage was sewed on three sides, and open on one side resembling a pillow case. Each organza sleeve was slipped over the tip of a shoot, thus enclosing the shoot, and tied to the shoot using a plastic tie. Two sleeve cages were set up per plant, across the 24 plants, for a total of 48 sleeve cages weekly. Females were allowed to oviposit for $6 \mathrm{~d}$. At this time, sleeve cages enclosing the shoots with leaves were cut off the plants, brought to the laboratory and stored in a freezer at $-20{ }^{\circ} \mathrm{C}$ to kill the ovipositing females. The leaves within the sleeve cages were collected, and the eggs were counted with the aid of a stereomicroscope. Data were pooled over dates, a mean calculated for each treatment, and analyzed using regression techniques.

NyMPHal SURVIVAL TO ADULTHOOD. Second instars were collected from the laboratory colony and transported to the field. At the field, nymphs were placed in groups of two into sleeve cages following the procedure described above. The sleeve cages with nymphs were placed enclosing shoots with no evidence of natural lace bug infestation or of natural enemies. Nymphs within sleeves were checked daily until adults were seen. Also, to determine nymphal survival on naturally infested leaves, empty sleeve cages, i.e., with no colony nymphs, were placed enclosing shoots with evidence of lace bug oviposition. When adults were 


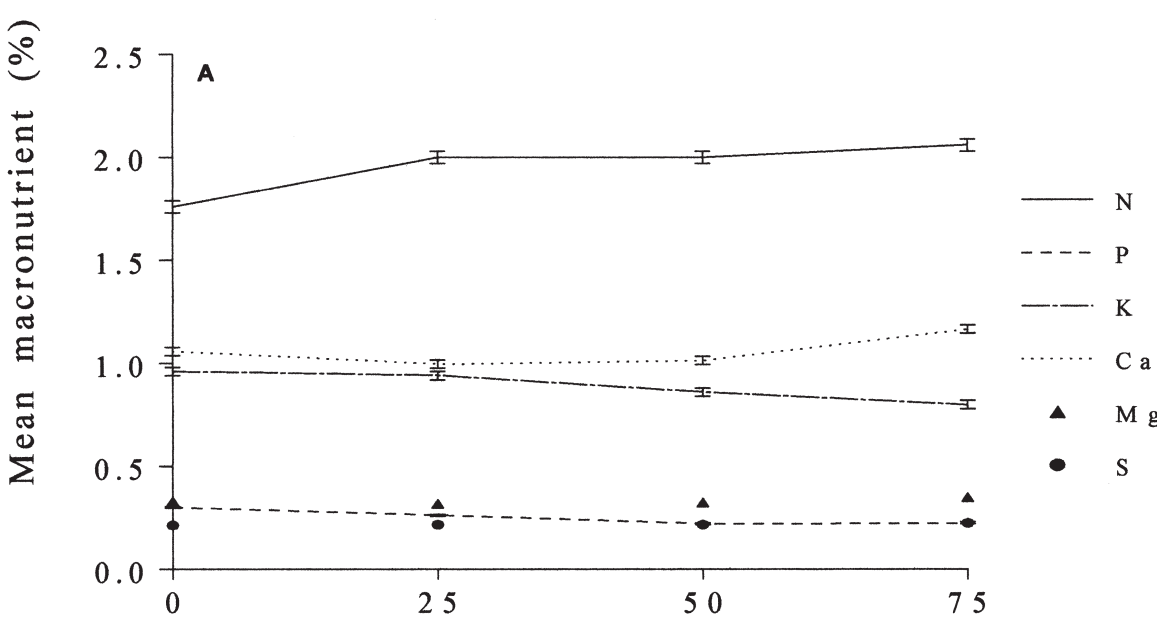

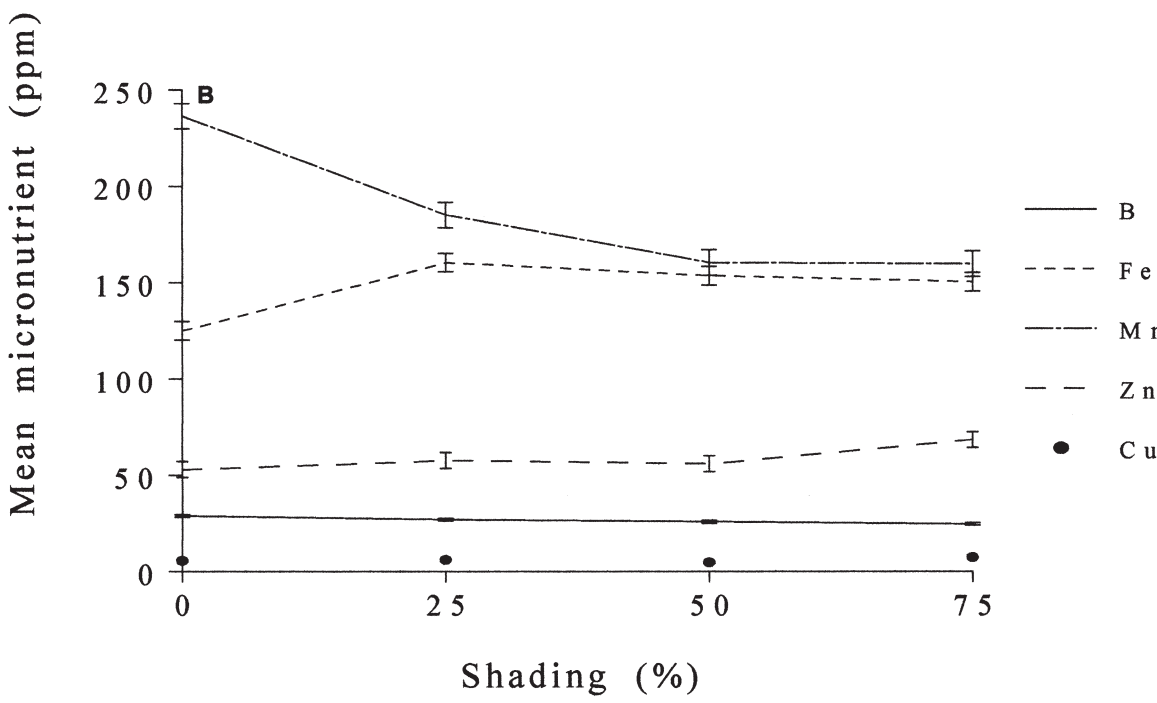

time were analyzed using a cumulative logit model within the SAS logistic procedure for ordinal data (SAS Institute, 1999).

Correlation analyses. The Pearson correlation analysis within SAS (SAS Institute, 1999) was used to correlate the mean number of laid eggs and of reared adults, and the mean injury with the mean leaf content of $\mathrm{N}, \mathrm{P}, \mathrm{K}$, $\mathrm{Ca}$, and the $\mathrm{C}: \mathrm{N}$ ratio.

\section{Results}

Overall, shading level significantly influenced the multivariate measurements of nutrient content of leaves (Wilks' Lambda $=$ $0.056 ; F=18.38 ; \mathrm{df}=11,12 ; P<0.0001)$ (Fig. 1A and B). The mean contents of $\mathrm{N}(t=$ 5.10; $\left.P<0.0001 ; R^{2}=0.54\right), \mathrm{Ca}(t=2.07 ; P$ $\left.=0.0503 ; R^{2}=0.16\right), \mathrm{Fe}(t=5.18 ; P<0.0001$; $\left.R^{2}=0.55\right)$, and $\mathrm{Zn}\left(t=2.78 ; P=0.0109 ; R^{2}=\right.$ 0.26 ), increased linearly with increases in the shading level. In contrast, the mean contents of $\mathrm{P}\left(t=-6.83 ; P<0.0001 ; R^{2}=0.68\right), \mathrm{K}(t=$ $\left.-4.54 ; P=0.0002 ; R^{2}=0.48\right), \mathrm{B}(t=-3.08$; $\left.P=0.0055 ; R^{2}=0.30\right)$, and $\mathrm{Mn}(t=-2.87 ; P$ $\left.=0.0090 ; R^{2}=0.27\right)$, decreased linearly with increased level of shading. Mean contents of $\mathrm{S}\left(t=1.72 ; P=0.1004 ; R^{2}=0.12\right), \mathrm{Mg}(t=$ $\left.1.86 ; P=0.0764 ; R^{2}=0.14\right)$, and $\mathrm{Cu}(t=1.47$; $\left.P=0.1566 ; R^{2}=0.09\right)$, were not significantly influenced by shading. The nutrient content data can be summarized with just four variables; N, P, K and Ca accounted for $>70 \%$ of the total variability (results not shown). The mean C:N ratio of leaves significantly decreased as the shading level increased $(\mathrm{F}$

Fig. 1. Effect of shading on the mean leaf element content. (A) Macronutrients (N: $y=1.824+0.004 x ; \mathrm{P}: y=0.292-0.001 x ; \mathrm{K}: y=0.972-0.002 x ; \mathrm{Ca}: y=1.007$ $+0.007 x)$. (B) Micronutrients (B: $y=28.80-0.06 x$; Fe: $y=130.99+0.64 x ; \mathrm{Mn}$ $y=217.62-0.66 x ; \mathrm{Zn}: y=52.11+0.18 x)$. Vertical bars represent $\pm \mathrm{SE}$

seen, sleeves enclosing the shoots were cut off, brought to the laboratory and stored in a freezer at $-20{ }^{\circ} \mathrm{C}$. Later, leaves were removed from within the sleeves, examined and adults counted. Two sleeve cages were set up per plant, across the 24 plants, for a total of 48 sleeve cages weekly. The experiment was repeated weekly from 6 August to 20 August 1998, and from 16 June to 2 July 1999. Data were pooled over dates, calculated as the mean percentage of nymphs that became adults per shading level, and analyzed using regression techniques.

Azalea lace bUg FeEding INJURy. Shoots were randomly collected from each plant on a weekly basis from 8 June until 20 Aug. 1999. Collected shoots were brought to the laboratory and given an injury score that represented the percentage of total shoot foliage showing insect feeding injury, i.e., stippling, caused by the wild population: $0=$ no evidence of feeding injury, 25 $=$ less than $25 \%$ of the leaves showed feeding injury, 50 $=$ about $50 \%$ of the leaves showed injury, $75=75 \%$ of the leaves showed insect injury, $100=$ almost all leaves showed feeding injury. The injury data collected over
$=-4.24 ; P=0.0513$ ) (Fig. 2).

The regression slope for the mean relative chlorophyll content of uninjured leaves was not significantly different from the regression slope of injured leaves $(\mathrm{F}=0.33$; $\mathrm{df}=1,7 ; P=$ 0.5977 ) (Fig. 3). Yet, the intercepts were significantly different $(\mathrm{F}=228.64 ; \mathrm{df}=2,4 ; P<0.0001)$. Although injured leaves contained significantly less chlorophyll than uninjured leaves,

Fig. 2. Effect of shading on the mean C:N ratio. Vertical bars represent \pm SE.

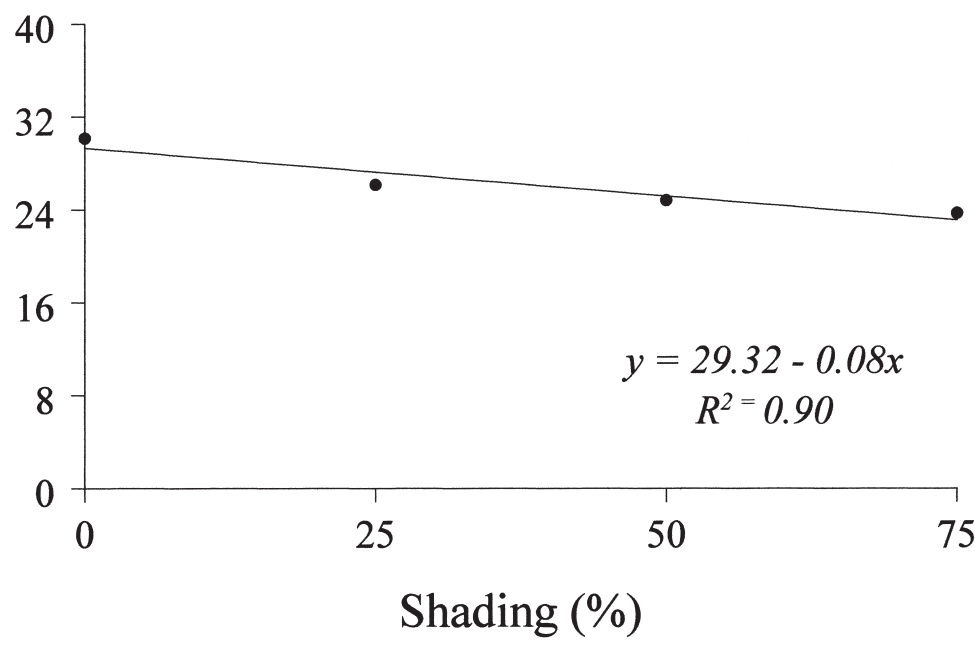




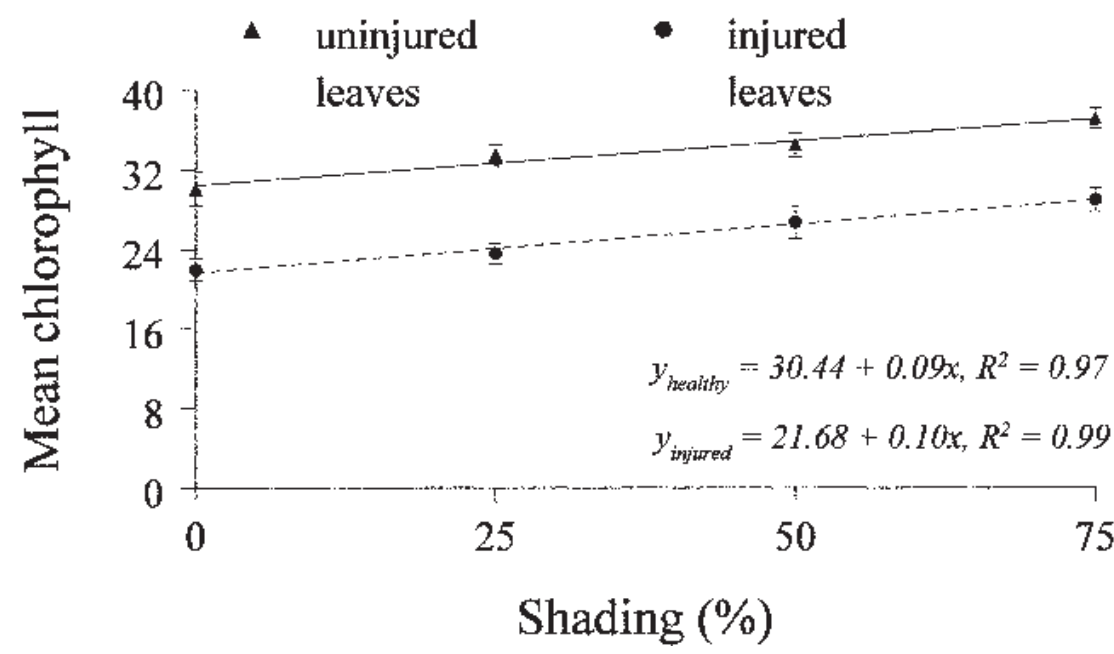

Fig. 3. Mean leaf chlorophyll content of plants grown under different shade levels. Vertical bars represent $\pm \mathrm{SE}$.

the mean relative chlorophyll content of leaves increased linearly with the level of shading.

Mean leaf area $\left(P=0.0122 ; R^{2}=0.98\right)($ Fig. 4A), and the mean moisture content of leaves $\left(P=0.0285 ; R^{2}=0.94\right)(\mathrm{Fig}$. 4B) increased linearly with increased shading. The mean trichome density decreased linearly with increased shading $\left(P=0.0170 ; R^{2}=0.97\right)$ (Fig. $\left.4 C\right)$.

The mean number of eggs laid by females confined to shoots increased linearly with the degree of shading $(\mathrm{F}=5.08 ; P=0.0366)$ (Fig. 5A). For both populations, the percent of nymphs reaching adulthood increased linearly with shading level (artificially infested: $t=5.10$, $P=0.0363$; naturally infested: $t=7.21 ; P=0.0187$ ) (Fig. 5B and C).

Azalea shoots suffered increased feeding injury as the season progressed, with the regression slopes $\left(\mathrm{P}^{2}=\right.$ 44.53; $P<0.0001)$ and intercepts (Wald $-\mathrm{P}^{2}=269.69 ; P$ $<0.0001$ ) for each shade level being significantly different from one another (Fig. 6). Unshaded plants suffered more feeding injury than shaded plants.

While the mean number of eggs laid $(r=0.98 ; P$ $=0.0161)$, and the mean number of reared adults $(r=$ $0.92 ; P=0.0416)$, were significantly and positively correlated with the mean leaf $\mathrm{N}$ content, the mean feeding injury was negatively correlated with leaf $\mathrm{N}$ content $(r=$ $-0.96 ; P=0.0354)$. Although these dependent variables were not correlated with $\mathrm{K}$ or $\mathrm{Ca}$, the mean number of eggs laid, and the mean number of reared adults were negatively correlated with the mean leaf Pcontent within leaves (eggs: $r=-0.99, P=0.0123$; adults: $r=-0.99, P$ $=0.0067$ ), and with the mean $\mathrm{C}: \mathrm{N}$ ratio (eggs: $r=-0.99$, $P=0.0115$; adults: $r=-0.98, P=0.0160)$. Mean feeding injury was positively correlated with leaf $\mathrm{P}$ content $(r$ $=0.99 ; P=0.0147)$ and with the $\mathrm{C}: \mathrm{N}$ ratio $=0.99, P=$ $0.0111)$, but negatively correlated with $\mathrm{N}(r=-0.96$ $P=0.0354)$

Fig. 4. Effect of shading on leaf measurements. (A) Mean leaf area. (B) Mean moisture content. (C) Mean number of trichomes within a 1-cm-diameter disk per leaf. Vertical bars represent $\pm \mathrm{SE}$.

\section{Discussion}

None of the plants in this study showed nutrient deficiency symptoms, except for the yellowish green leaves of the full sun plants. The nitrogen content of the azaleas in this study appears to be higher than that reported by Casey and Raupp (1999) for container-grown plants fertilized with different levels of nitrogen fertilizer. This difference appears to be related to the loss of applied nitrogen through leaching. Comparison of the mean amount of each leaf element of azaleas in this study with the internal concentrations considered adequate for most higher plants listed by Salisbury and Ross (1985) indicated that the azaleas had enough of each essential element to prevent deficiency symptoms and maintain their ability to grow and develop. Thus, differences obtained among sunny and shaded plants resulted from the effect of light intensity on the physiological functions and processes of the plant as an environmental stress (Levitt, 1972).

Application of nitrogen fertilization has been shown to increase the nitrogen content of azaleas (Casey and Raupp, 1999). Higher leaf $\mathrm{N}$ content in shaded plants may result in more efficient photosynthesis. Low $\mathrm{N}$ content in sun leaves may result from lower levels of proteins (Salisbury and Ross, 1985), or insect feeding
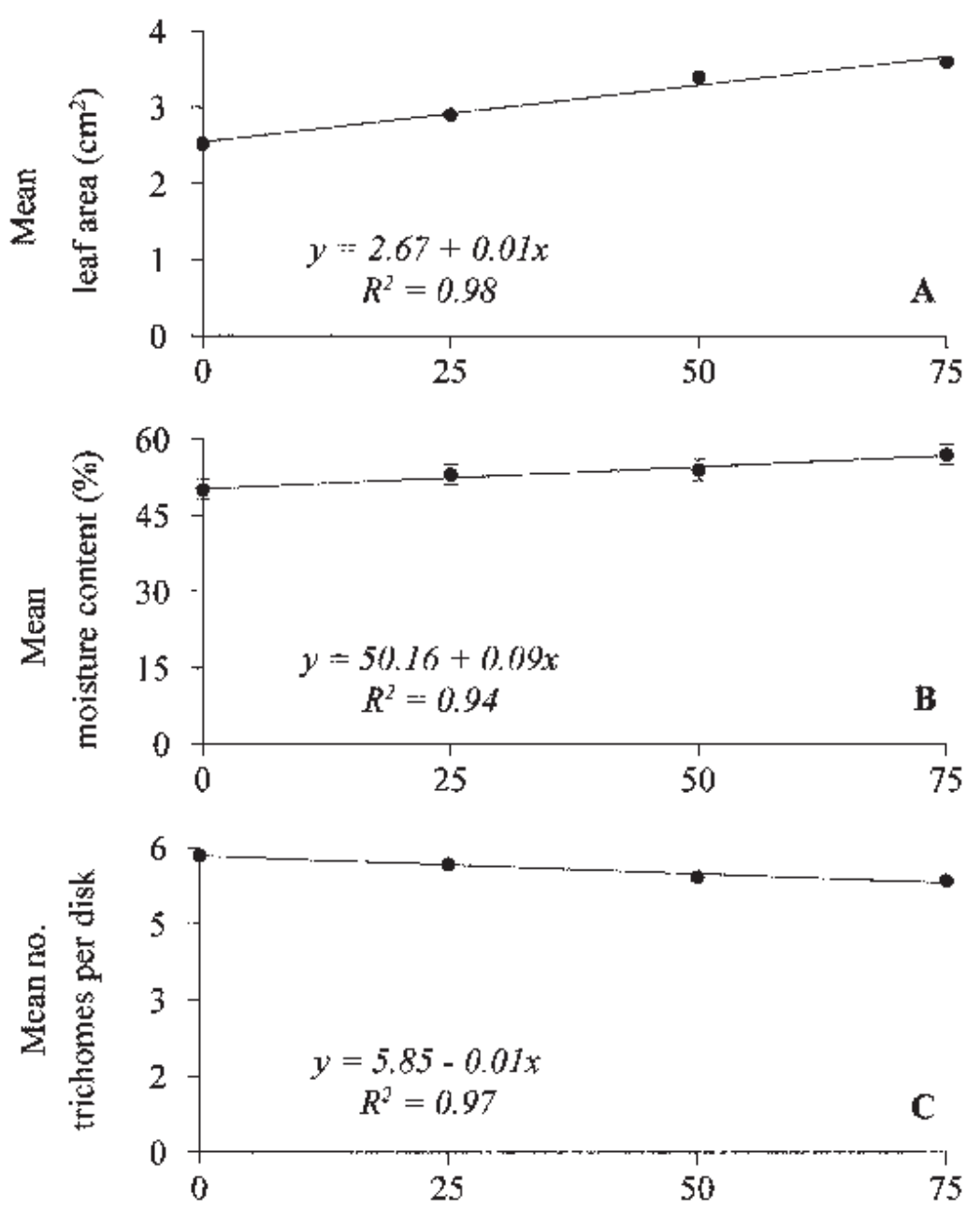

Shading (\%) 


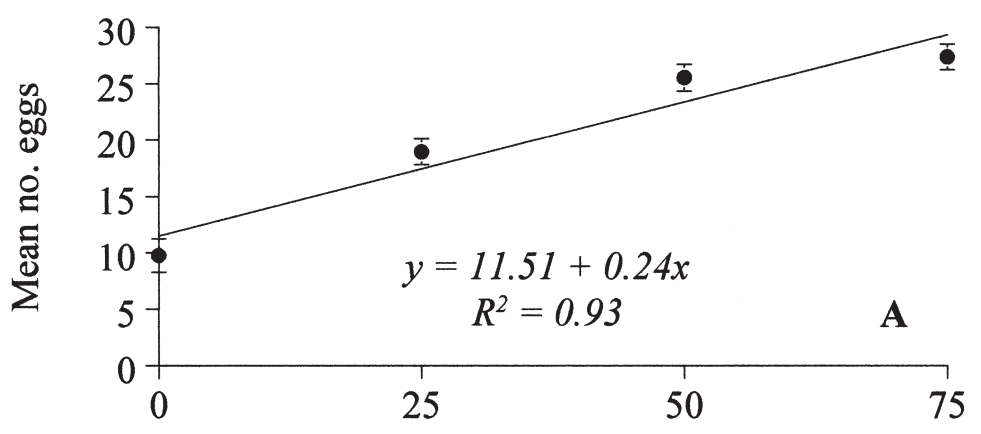

defenses such as tannins or phenolic compounds. Although these plants were not readily suitable for oviposition, survival, and development suggesting a nonpreference or antibiosis mechanism of resistance (Painter, 1968), unshaded plants suffered greater feeding injury than shaded plants.

Although injured leaves contained less chlorophyll than uninjured leaves, consistent with the results of Klingeman et al. (2000), those that were shaded contained higher levels of chlorophyll than sunny leaves. Buntin et al. (1996) observed that lace bugs insert their stylets through stomata on the lower

75 leaf surface, penetrate spongy mesophyll parenchyma intercellularly, and selectively pierce and remove palisade cell

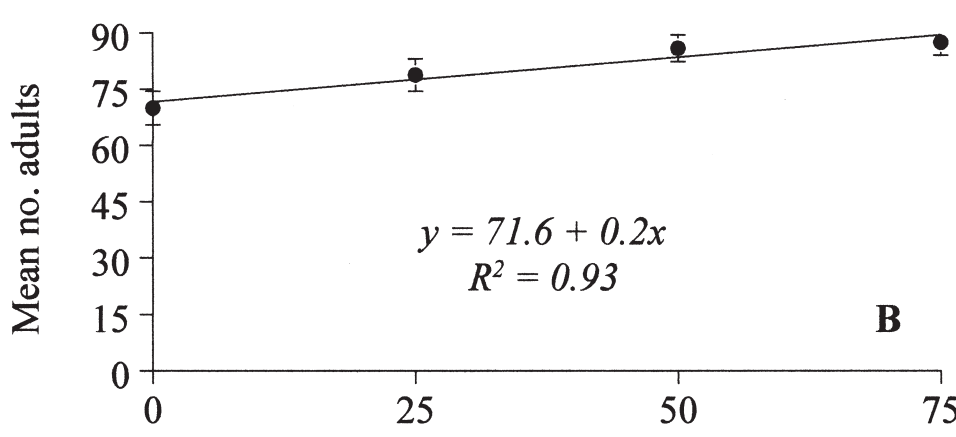
contents, i.e., chloroplasts. Consequently, photosynthesis in the remaining cells and leaf respiration are reduced. Reduced chlorophyll content of sunny leaves may have been due to the increased feeding of lace bugs on these leaves.

Braman et al. (2000) found that 50\% shading had little effect on azalea leaf area when compared to azaleas in full sun. Yet, this study showed that shading increased the mean leaf area, which is the generalized leaf response to reduced light level (Salisbury and Ross, 1985). With increasing leaf expansion, a corresponding decrease in trichome density 5 would be expected because the number of trichomes is determined early in leaf development (Unzelman and Healey,

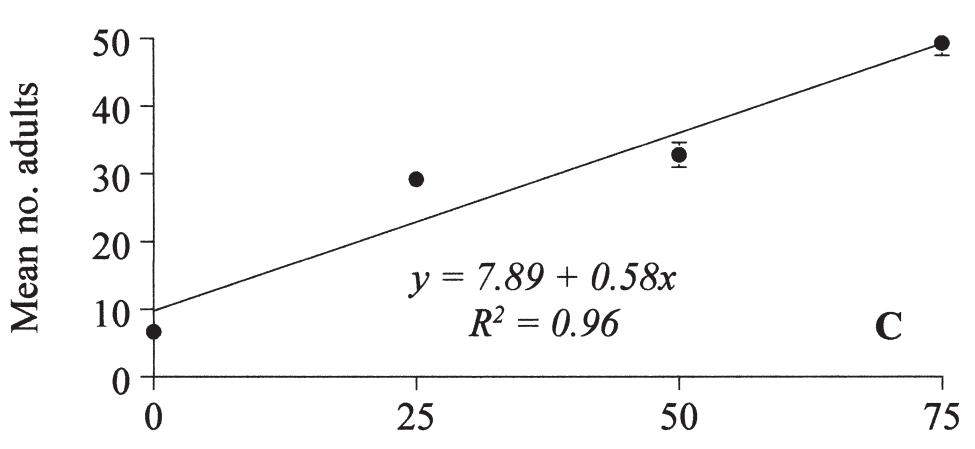

1974). Currently, the mean trichome density decreased with increased level of shading, probably as the result of leaf expansion or cell enlargement. The lower leaf trichome density under shade could have resulted from the leaf investing more energy into producing chlorophyll pigments to maximize light absorption (Salisbury and Ross, 1985) at the expense of the energy required by the epithelial cells to produce new trichomes (Unzelman and Healey, 1974).

Generally, sun leaves are thicker (Givnish, 1988), and 75 weigh more per unit leaf area (Salisbury and Ross, 1985). In this study, the mean moisture content of leaves increased linearly with level of shading. Consequently, the dry weight of the leaves, i.e., biomass, decreased as shading level increased. Higher moisture within shaded leaves could explain, Shading $(\%)$

Fig. 5. Effect of shading on the azalea lace bug. (A) Mean number of eggs laid by female lace bugs confined to shoots. (B) Mean nymphal survivorship on artificially infested shoots. (C) Mean nymphal survivorship on naturally infested shoots. Vertical bars represent $\pm \mathrm{SE}$.

in part, higher acceptability of these leaves for oviposition. Neal and Bentz (1997) showed that eggs of the azalea lace bug are noncleidoic and that the chorion is both permeable and elastic,

Fig. 6. Effect of shading on the mean percentage of azalea shoots showing feeding injury over time. Vertical bars represent $\pm \mathrm{SE}$.

(Buntin et al., 1996). Higher $\mathrm{N}$ content in leaves from shaded versus sunny plants also has been observed for other plant species (Schaffer and Gaye, 1989; Schaffer and Mason, 1990; Syvertsen and Smith, 1984). Iron is one of the most important micronutrients for azaleas (Galle, 1987), and this study showed that the foliar Fe content increases with shading. As in this study, Ingram et al. (1979), found that the Ca content of azaleas grown in the shade was higher than those grown in the sun.

The C:N ratio has been used as an indicator of plant susceptibility to insect attack under different growing conditions. Bryant et al. (1983) speculated that plants provided with adequate light, even when subjected to suboptimal nutrient availability, should exhibit a high C: $\mathrm{N}$ ratio and resistance to herbivory, because the surplus $\mathrm{C}$ would result in accumulation of carbon-based secondary substances. Although the C:N ratio was significantly higher for unshaded plants, it was not determined in this study if these plants contained higher content of carbon-based

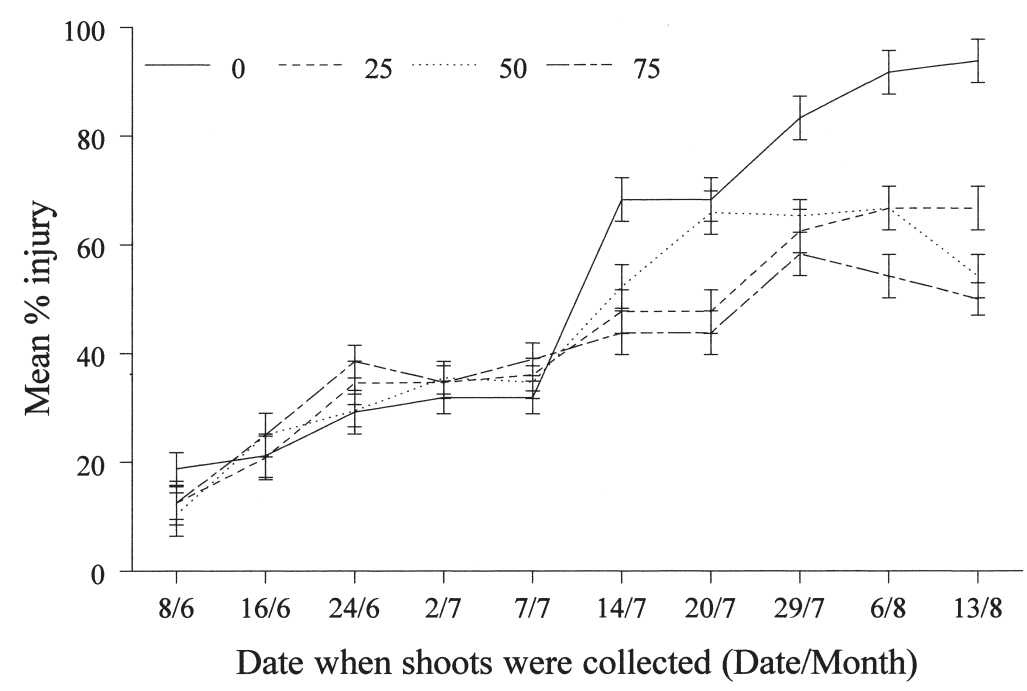


thus, additional moisture is required for embryo development and hatching. In contrast, although deciduous azaleas differ in water content and leaf pubescence, these variables were not involved in azalea lace bug resistance (Wang et al., 1998).

Ovipositing female lace bugs and nymphs were confined to individual shoots, thus they probably laid eggs and fed according to the nutritional suitability of the leaves, or in response to stimuli received during feeding (Carlson and Hibbs, 1970). It is possible that shaded leaves are more readily accepted for oviposition than sunny leaves due to the succulence of the leaf, which would facilitate penetration of the ovipositor into the leaf, and because higher moisture content ensures embryo development and hatching. Lower lace bug survivorship on sunny azaleas may be due, in part, to the decreasing availability of suitable feeding sites for nymphal growth and development. Schultz (1993) described that lace bugs prefer to feed on the previous year's growth while the new foliage matures. Thus, it is not until the foliage from the previous year dies, that the new foliage gets attacked. While the regrowth flush in shaded azaleas depends on temperature and rainfall, sunny azaleas have few additional leaf flushes after the blooming period or during the summer season (unpublished data). Also, higher nymphal mortality on sunny plants could be caused by nutritional limitations as these plants contained the lowest $\mathrm{N}$ content (Mattson, 1980).

In this study, all the plants suffered feeding injury, ranging from mild to severe stippling on the upper surface and necrotic leaf margins. However, plants fully exposed to the sun suffered greater injury than the other plants. It could be that the azalea lace bug increases host feeding on susceptible sunny plants at least partly as a compensatory response to lower moisture content (Trumbule and Denno, 1995), or to the lower availability of N (Slansky and Scriber, 1985). Leaf composition generally changes throughout the season and, as a consequence, the quality of leaves as food may also change (Kooi et al., 1991). Because the amount of injury on sunny plants increased as the season progressed, it appears that some physiological or biochemical change had occurred in these plants that made them more suitable or preferred for lace bug colonization and development at low numbers, or less tolerant to insect feeding. Also, it is possible that the degree of susceptibility is not consistently related to the $\mathrm{N}$ concentration in leaves, but to the appropriate concentrations and ratios of required nutrients and non-nutritive compounds, such as phagostimulants, whose levels are limited by the plants' essential elements (Salisbury and Ross, 1985). Although azaleas under the $75 \%$ shade level were highly suitable for oviposition and nymphal development, these plants showed very little visible evidence of feeding injury. Similarly, Casey and Raupp (1999) found that plants with elevated nitrogen levels after being fertilized were preferentially chosen by azalea lace bugs but did not exhibit greater levels of leaf injury. It was not determined in the present study if the $75 \%$ shaded plants were more tolerant because of plant vigor, growth of new plant parts, or ability to repair injured parts of the plant. The principal components analyses indicated that $\mathrm{N}, \mathrm{P}, \mathrm{K}$, and $\mathrm{Ca}$ accounted for much of the elemental variation among plants. Thus, emphasis could be placed on these elements in future research investigating induced resistance against the azalea lace bug, or on epicuticular lipid composition induced-changes (Wang et al., 1999).

This study shows that azaleas grown under different shading regimes differ in several plant characters that, in turn, influence the performance of the azalea lace bug. In contrast to Maiorana's (1981) argument, differential mortality of lace bugs among shaded and sunny plants was not related to predation (data not shown), but to changes in the suitability of the plants. Shaded plants are of better quality as hosts (White, 1984), yet these plants can tolerate infestations by the lace bug.

\section{Literature Cited}

Aiken, L.S. and S.G. West. 1991. Multiple Regression: Testing and interpreting interactions. Sage Publ., Newbury Park, Calif.

Bodson, M. 1983. Effect of photoperiod and irradiance on floral development of young plants of a semi-early and a late cultivar of azalea. J. Amer. Soc. Hort. Sci. 108:382-386.

Braman, S.K. and A.F. Pendley. 1992. Evidence for resistance of deciduous azaleas to azalea lace bug. J. Environ. Hort. 10:40-43.

Braman, S.K., J.G. Latimer, R.D. Oetting, R.D. McQueen, T.B. Eckberg, and M. Prinster. 2000. Management strategy, shade, and landscape composition effects on urban landscape plant quality and arthropod abundance. J. Econ. Entomol. 93:1464-1472.

Bryant, J.P., F.S. Chapin, III, and D.R. Klein. 1983. Carbon/nutrient balance of boreal plants in relation to vertebrate herbivory. Oikos 40 357-368.

Bultman, T.L. and S.H. Faeth. 1988. Abundance and mortality of leaf miners on artificially shaded emory oak. Ecol. Entomol. 13:131-142.

Buntin, G.D., S.K. Braman, D.A. Gilbertz, and D.V. Phillips. 1996. Chlorosis, photosynthesis, and transpiration of azalea leaves after azalea lace bug (Heteroptera: Tingidae) feeding injury. J. Econ. Entomol. 89:990-995.

Carlson, O.V and E.T. Hibbs. 1970. Oviposition by Empoasca fabae (Homoptera: Cicadellidae). Ann. Entomol. Soc. Amer. 63:516-519.

Casey, C.A. and M.J. Raupp. 1999. Effect of supplemental nitrogen fertilization on the movement and injury of azalea lace bug (Stephanitis pyrioides (Scott)) to container-grown azaleas. J. Environ. Hort. 17:95-98.

Coffelt, M.A. and P.B. Schultz. 1988. Influence of plant growth regulators on the development of the azalea lace bug. J. Econ. Entomol. 81: 290-292.

Collinge, S.K. and S.M. Louda. 1988. Herbivory by leaf miners in response to experimental shading of a native crucifer. Oecologia 75: 559-566.

Crone, E.E. and C.G. Jones. 1999. The dynamics of carbon-nutrient balance: Effects of cottonwood acclimation to short and long_term shade on beetle feeding preferences. J. Chem. Ecol. 25:635-656.

Dudt, J.F. and D.J. Shure. 1994. The influence of light and nutrients on foliar phenolics and insect herbivory. Ecology 75:86-98.

Galle, F.C. 1987. Azaleas. Timber Press, Portland, Ore

Givnish, T.J. 1988. Adaptation to sun and shade: a whole plant perspective. Australi. J. Plant Physiol. 15:63-92.

Hendricks, S.B. and H.A. Borthwick. 1963. Control of plant growth by light, p. 233-263. In: L.T. Evans (ed.). Environmental control of plants. Academic Press, N.Y.

Ingram, D.L., C.R. Johnson, and J.N. Joiner. 1979. Effects of shade, nitrogen and potassium levels on container grown azaleas Rhododendron obtusum and ligustrum Ligustrum japonicum. Proc. S.N.A. Res. Conf. Annu. Rpt. Southern Nurserymen's Assn. Nashville, Tenn. 24: 65-66.

Kessell, M. 1990. Rhododendrons and azaleas. Blanford, Sterling Publishing, New York.

Kintz, J.L. and D.R. Alverson. 1999. The effects of sun, shade, and predation on azalea lace bug populations in containerized azaleas. HortTechnology 9:638-641.

Klingeman, W.E., M.W. van Iersel, G.D. Buntin, and S.K. Braman. 2000. Whole-plant $\mathrm{CO}_{2}$ exchange measurements on azaleas injured by azalea lace bug (Heteroptera: Tingidae) feeding. J. Econ. Entomol. 93:352-356.

Kooi, R.E., T.P.M. Van de Water, and W.M. Herrebout. 1991. Food acceptance by a monophagous and an oliphagous insect in relation to seasonal changes in host plant suitability. Entomol. Expt. Appl. 59:111-122.

Levitt, J. 1972. Responses of plants to environmental stresses. Academic Press, N.Y. 
Lincoln, D.E. and H.A. Mooney. 1984. Herbivory on Diplacus aurantiacus shrubs in sun and shade. Oecologia (Berlin) 64:173-176.

Louda, S.M. and J.E. Rodman. 1996. Insect herbivory as a major facto in the shade distribution of a native crucifer (Cardamine cordifolia A. Gray, bittercress). J. Ecol. 84:229-237.

Maiorana, V.C. 1981. Herbivory in sun and shade. Biol. J. Linnean Soc. $15: 151-156$.

Mattson, W.J. 1980. Herbivory in relation to plant nitrogen content. Annu. Rev. Ecol.11:119-161.

Mohr, H. 1964. The control of plant growth and development by light. Biol. Rev. 39:87-112.

Neal, Jr., J.W. and J. Bentz. 1997. Physical dynamics of the noncleidoic egg of Stephanitis pyrioides (Heteroptera: Tingidae) during development. Environ. Entomol. 26:1066-1072.

Neal, Jr., J.W. and L.W. Douglass. 1988. Development, oviposition rate, longevity, and voltinism of Stephanitis pyrioides (Heteroptera: Tingidae), an adventive pest of azalea at three temperatures. Environ. Entomol. 17:827-831.

Painter, R.H 1968. Insect resistance in crop plants. Univ. Press Kan., Lawrence.

Pettersen, H. 1976. Effects of light and growth retardants on dormancy in greenhouse azaleas. Acta Hort. 64:165-173.

Potter, D.A. 1992. Abundance and mortality of a specialist leafminer in response to experimental shading and fertilization of American holly. Oecologia 91:14-22.

Raupp, M.J. 1984. Effects of exposure to sun on the frequency of attack by the azalea lace bug. J. Amer. Rhododendron Soc. 38:189-190.

Rowe, II, W.J. and D.A. Potter. 2000. Shading effects on susceptibility of Rosa spp. to defoliation by Popillia japonica (Coleoptera: Scarabaeidae). Environ. Entomol. 29:502-508.

Salisbury, F.B. and C.W. Ross. 1985. Plant physiology. Wadsworth Publishing, Belmont, Calif.

SAS Institute. 1999. SAS user's guide: Statistics. SAS Inst., Cary, N.C. Schaffer, B. and G.O. Gaye. 1989. Gas exchange, chlorophyll and ni- trogen content of mango leaves as influenced by light environment HortScience 24:507-509.

Schaffer, B. and L.J. Mason. 1990. Effects of scale insect herbivory and shading on net gas exchange and growth of a subtropical tree species (Guaiacum sanctum L.). Oecologia 84:468-473.

Schultz, P.B. 1993. Host plant acceptance of azalea lace bug (Heteroptera: Tingidae) for selected azalea cultivars. J. Entomol. Sci. 28:230-235. Shrewsbury, P.M. and M.J. Raupp. 2000. Evaluation of components of vegetational texture for predicting azalea lace bug, Stephanitis pyrioides (Heteroptera: Tingidae), abundance in managed landscapes. Environ. Entomol. 29:919-926.

Scriber, J.M. 1984. Host-plant suitability, p. 159-202. In: W.J. Bell, and R.T. Carde (eds.). Chemical ecology of insects. Chapman Hall, London.

Slansky, Jr., F. and J.M. Scriber. 1985. Food consumption and utilization, p. 87-163. In: G.A. Kerkut and L.I. Gilbert (eds.). Comprehensive insect physiology, biochemistry and pharmacology. Pergamon Press, Oxford.

Syvertsen, J.P. and M.L. Smith. 1984. Light acclimatization in citrus leaves: I. Changes in physical characteristics, chlorophyll, and nitrogen content. J. Amer. Soc. Hort. Sci. 109:807-812.

Trumbule, R.B. and R.F. Denno. 1995.Light intensity, host plant irrigation and habitat-related mortality as determinants of the abundance of azalea lace bug (Heteroptera: Tingidae). Environ. Entomol. 24:898-908.

Unzelman, J.M. and P.L. Healey. 1974. Development, structure, and occurrence of secretory trichomes of Pharbitis. Protoplasma 80:285-303.

Wang, Y., C.D. Robacker, and S.K. Braman. 1998. Identification of resistance to azalea lace bug among deciduous azalea taxa. J. Amer. Soc. Hort. Sci. 123:592-597.

Wang, Y., S.K. Braman, C.D. Robacker, and J.G. Latimer. 1999. Composition and variability of epicuticular lipids of azaleas and their relationship to azalea lace bug resistance. J. Amer. Soc. Hort. Sci. 124:239-244.

White, T.C.R. 1984. The abundance of invertebrate herbivory in relation to the availability of nitrogen in stressed food plants. Oecologia 63:90-105. 